Paula Gamus

Milena Grzelka

Koło Naukowe Bibliotekoznawców

Uniwersytet Łódzki

\title{
Powieść historyczna w zasobach polskich bibliotek cyfrowych
}

Referat jest próbą przeanalizowania zasobów polskich bibliotek cyfrowych pod względem posiadanych przez nie dokumentów klasyfikowanych jako powieści historyczne. Powieść historyczna, początkowo nazywana również romansem historycznym, to odmiana powieści, w której świat przedstawiony został umieszczony w epoce traktowanej przez autora i odbiorców tekstu jako zamknięty okres dziejów ${ }^{1}$. Na powieść historyczną składają się fakty historyczne połączone z fikcją literacką, przy czym wymagana jest od pisarza w miarę ścisła wierność wobec faktów wydarzeń historycznych. Charakterystycznym wyróżnikiem gatunku jest umieszczenie obok bohaterów fikcyjnych prawdziwych postaci historycznych. Jako początek powstania gatunku uważany jest powszechnie rok 1814, w którym Walter Scott wydał „Waverley”, utwór uważany za początek tej odmiany powieści ${ }^{2}$. Biorąc pod uwagę powyższy fakt nietrudno stwierdzić, że w poniższym opracowaniu przeważać będa powieści wydane po 1814 roku.

W Polsce istnieje dostęp do kilkudziesięciu bibliotek cyfrowych, których organizatorami są różnego rodzaju instytucje, zazwyczaj o profilu naukowym. Organem zrzeszającym te biblioteki jest Federacja Bibliotek Cyfrowych (FBC). Serwis internetowy FBC ma na celu ułatwienie korzystania z cyfrowych zasobów poprzez udostępnienie narzędzia umożliwiającego symultaniczne ich przeszukiwanie. Twórcy prowadzą również statystyki dotyczące zbiorów gromadzonych w bibliotekach cyfrowych, dzięki którym wiadomo, że wiodącą biblioteką pod względem liczby udostępnionych cyfrowo publikacji jest Wielkopolska Biblioteka Cyfrowa, posiadająca obecnie 162334 zdigitalizowane jednostki. Łącznie we wszystkich bibliotekach udostępniono 965853 dokumentów ${ }^{3}$.

${ }^{1}$ Słownik terminów literackich. Red. M. Głowiński. Wrocław: Zakład Narodowy im. Ossolińskich, 1989, s. 381.

${ }^{2}$ Stownik rodzajów i gatunków literackich. Pod red. G. Gazdy, S. TyneckiejMakowskiej. Kraków: „Universitas”, 2006, s.568.

${ }^{3}$ Stan na dzień 9 maja 2012 r. 
Autorki opracowania kierując się chęcią pozyskania jak najdokładniejszych wyników postanowiły, że do celów badawczych wykorzystają możliwości portalu FBC, który pozwala na jednoczesne przeszukanie zbiorów wszystkich zrzeszonych w nim bibliotek. Celem badania było zdobycie informacji na temat dostępu do powieści historycznych w bibliotekach cyfrowych, których entuzjaści gatunku mogą właśnie tam poszukiwać. Aby pozyskać dane do opracowania, w narzędziu wyszukiwawczym FBC wpisano słowa kluczowe „powieść historyczna” uzyskując tym samym wyniki, które spełniały określone kryterium; w sumie 551 pozycji. Jako że poszukiwano jedynie pozycji książkowych, z wyników wykluczono powieść historyczną publikowaną w odcinkach na łamach czasopism oraz opracowania krytycznoliterackie. W rezultacie uzyskano 473 woluminy udostępniane przez 17 bibliotek cyfrowych. Najwyższy wynik został odnotowany w Polskiej Bibliotece Internetowej - 295 pozycji, co stanowi $62 \%$ całości wszystkich odnalezionych publikacji. Kolejne biblioteki, w których zasobach wyszukano znaczącą liczbę poszukiwanych pozycji, to: Centralna Biblioteka Narodowa Polona 79 tytułów, co stanowi 17\% pozyskanego ogółu oraz Dolnośląska Biblioteka Cyfrowa z 57 tytułami, czyli $12 \%$ z 473 jednostek. Zasób kolejnych bibliotek nie jest już tak pokaźny, jak w przypadku wcześniejszych. Gdańska Biblioteka Cyfrowa udostępnia 8 pozycji czyli $2 \%$ wszystkich powieści historycznych. oraz Podlaska Biblioteka cyfrowa dysponuje 6 tytułami stanowiącymi $1 \%$ całości. W zbiorach pozostałych 12 bibliotek znajduje się od 1 do 4 powieści historycznych - mniej niż 1\% ogółu.

Tab. 1. Liczba tytułów w poszczególnych bibliotekach cyfrowych

\begin{tabular}{|l|c|c|}
\hline Nazwa biblioteki cyfrowej & Liczba pozycji & $\mathbf{\%}$ \\
\hline Polska Biblioteka Internetowa & 295 & 62 \\
\hline Centralna Biblioteka Narodowa Polona & 79 & 17 \\
\hline Dolnośląska Biblioteka Cyfrowa & 57 & 12 \\
\hline Gdańska Biblioteka Cyfrowa & 8 & 2 \\
\hline Podlaska Biblioteka Cyfrowa & 6 & 0, \\
\hline Bałtycka Biblioteka cyfrowa & 4 & 0,8 \\
\hline Opolska Biblioteka Cyfrowa & 4 & 0,8 \\
\hline Podkarpacka Biblioteka Cyfrowa & 3 & 0,6 \\
\hline Jagiellońska Biblioteka Cyfrowa & 2 & 0,4 \\
\hline Radomska Biblioteka Cyfrowa & 2 & 0,4 \\
\hline Chełmska Biblioteka Cyfrowa & & \\
\hline
\end{tabular}




\begin{tabular}{|l|c|c|}
\hline Kujawsko-Pomorska Biblioteka Cyfrowa & 2 & 0,4 \\
\hline $\begin{array}{l}\text { E-biblioteka Uniwersytetu Warszaw- } \\
\text { skiego }\end{array}$ & 2 & 0,4 \\
\hline Elbląska Biblioteka Cyfrowa & 2 & 0,4 \\
\hline Biblioteka Cyfrowa UMCS & 1 & 0,2 \\
\hline $\begin{array}{l}\text { Biblioteka Cyfrowa Regionalia Ziemi } \\
\text { Łódzkiej }\end{array}$ & 1 & 0,2 \\
\hline Pomorska Biblioteka Cyfrowa & $\mathbf{4 7 3}$ & 100 \\
\hline Suma & 1 & 0,2 \\
\hline
\end{tabular}

Źródło: opracowanie własne na podst. www. fbc.pionier.net.pl.

Głównym celem Polskiej Biblioteki Internetowej jest ułatwienie edukacji osobom najczęściej spoza dużych miast, znacznie oddalonych od ośrodków akademickich i kulturalnych, toteż nie dziwi fakt, iż w niej właśnie znajduje się najwięcej powieści historycznych. Natomiast Centralna Biblioteka Narodowa Polona stara się przede wszystkim chronić zaniedbane zbiory przed całkowitym zniszczeniem, dlatego prawdopodobnie posiada ona pokaźną liczbę powieści historycznych. Dolnośląska Biblioteka Cyfrowa udostępnia wiele wartościowych i ciekawych pozycji z gatunku, między innymi są to lektury Quo Vadis oraz Potopu Henryka Sienkiewicza.

Wyniki badania zdominowała twórczość autora, który posiada najwięcej wydanych książek w historii literatury polskiej. Mowa tu o dziewiętnastowiecznym pisarzu, publicyście i wydawcy Józefie Ignacym Kraszewskim. Pośród 473 pozycji aż 76 jest jego autorstwa. Między innymi Szaławita, Rzym za Nerona, „Stara baśń czy Hrabina Cosel. Kolejnym popularnym twórca jest Jadwiga Papi (1843-1906), pedagog i autorka książek dla młodzieży o tematyce historycznej ${ }^{4}$. W spisie odnaleziono 29 książek jej autorstwa, w tym Rycerz btękitny, Dwa gniazda oraz Za oceanem. Trzecim autorem publikacji chętnie zamieszczonych przez biblioteki cyfrowe jest powieściopisarz i poeta z XIX wieku, Zygmunt Kaczkowski. Wśród jego 20 książek użytkownicy bibliotek cyfrowych mogą znaleźć m. in. Sodalis Marianus: powieść historyczna ze starych ksiag i papierów, Wasi ojcowie, czy Bracia ślubni.

Wykres 1 prezentuje nazwiska autorów, których powieści w spisie wystąiły przynajmniej dziesięć razy.

${ }^{4}$ Nowy leksykon PWN. Red. prow. Andrzej Dyczkowski. Warszawa: PWN, 1998, s. 1269. 


\section{Wykr. 1. Autorzy powieści historycznych z największą liczbą publikacji w bibliotekach cyfrowych}

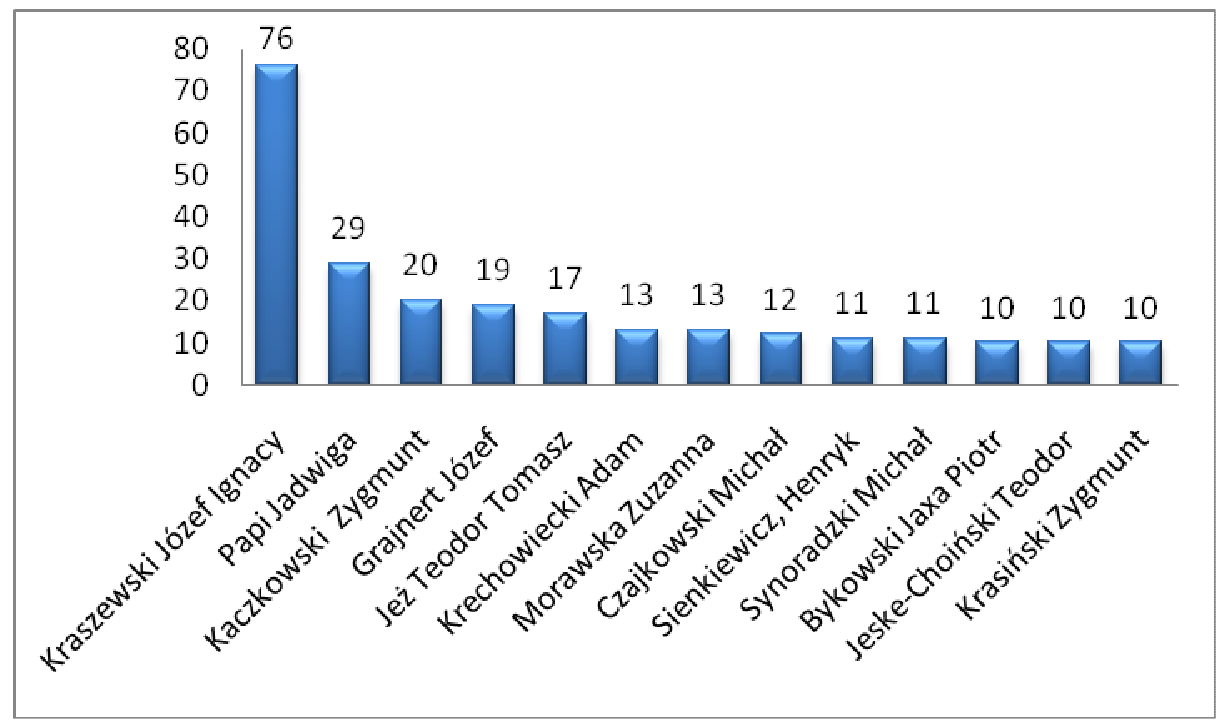

Źródło: opracowanie własne na podst. www. fbc.pionier.net.pl.

Spośród 98 pisarzy, których twórczość zakwalifikowała się do spisu, 37 to autorzy $\mathrm{z}$ jedną publikacją w zbiorach bibliotek, 19 twórców - z dwoma tytułami, 11 - z trzema powieściami, 3 - z czterema. Pozostałych piętnastu jest autorami od 5 do 9 pozycji, które znalazły się w zbiorach bibliotek cyfrowych.

Biblioteki cyfrowe udostępniając gromadzoną literaturę nie mogą łamać praw autorskich, stąd pozycje przez nie zdigitalizowane w znacznej mierze należą do tzw. domeny publicznej, co pozwala na ich zgodne z prawem publiczne rozpowszechnianie. Pomimo tych ograniczeń liczba powieści historycznych w nich odnaleziona może być uważana za satysfakcjonująca. Ze względu na prawne ograniczenia tytuły udostępniane przez biblioteki cyfrowe pochodzą w głównej mierze z XIX wieku - jest to 305 pozycji. Pojawiają się jednak zarówno pozycje młodsze z XVIII jak i te z XX wieku. Cześć dokumentów ze spisu była niemożliwa do sklasyfikowania pod względem chronologicznym, łącznie odnotowano 36 takich pozycji.

Dość interesujący w tym wypadku jest fakt, iż powieści pochodzące z Polskiej Biblioteki Internetowej w swoim opisie nie posiadały daty wydania, mimo iż taka informacja znajdowała się na stronie tytułowej książki. Na po-

${ }^{5}$ Spotykane są publikacje, do których dostęp jest płatny lub które udostępniane są tylko na komputerach danej biblioteki. Przykładem takiego dzieła jest powieść Litwin i Andegawenka z 1974 r. udostępniana przez Centralną Bibliotekę Narodową Polona. 
trzeby badania, kiedy było to możliwe, datę publikacji określono lub oszacowano. Braki w opisach dziwią tym bardziej, że od 2008 roku prace nad rozbudową Polskiej Biblioteki Internetowej prowadzi Biblioteka Narodowa ${ }^{6}$. Problem ten można próbować tłumaczyć tym, że braki te powstały jeszcze przed tą zmianą, gdyż większość tych publikacji wpłynęło do Polskiej Biblioteki Internetowej przed rokiem 2008. Mimo to Biblioteka Narodowa powinna dążyć do poprawienia opisu wymagających tego dokumentów. Poniższa tabela przedstawia liczbę pozycji pochodzącą z danego okresu.

\section{Tab. 2. Wiek wydania powieści historycznych}

\begin{tabular}{|l|l|}
\hline Wiek & Liczba tytułów \\
\hline XVIII w. & 4 \\
\hline XIX w. & 305 \\
\hline XX w. & 128 \\
\hline bez daty wydania & 36 \\
\hline
\end{tabular}

Źródło: opracowanie własne na podst. www.fbc.pionier.net.pl.

Literatura gromadzona $w$ polskich bibliotekach cyfrowych jest dobierana głównie z myślą o mieszkańcach naszego kraju. Biblioteki cyfrowe dążą do ochrony dorobku kulturowego, a co za tym idzie - digitalizowane są w pierwszej kolejności druki polskie. Dlatego też, jak wynika z informacji udostępnianych w opisach poszczególnych powieści bądź na ich stronach tytułowych, większość z cyfrowych pozycji jest pochodzenia polskiego i tylko 17 dokumentów z 456 (prawie 4\%) stanowi przekład z obcych języków.

Mimo iż zbiory bibliotek cyfrowych zaczęły w znacznym stopniu przyrastać dopiero po roku $2008^{7}$, liczba odnalezionych przez badaczki powieści historycznych plasuje się na zadowalającym poziomie: spośród 10579 wszystkich powieści znajdujących się w bibliotekach cyfrowych 551 wytypowanych to powieść historyczna (przeszło 5\% wszystkich powieści udostępnianych przez biblioteki cyfrowe zrzeszone w FBC).

Udostępniane elektroniczne wersje książek z pewnością stanowią duże ułatwienie dla osób, dla których dostęp do książki w postaci drukowanej jest utrudniony. Większość bibliotek udostępnia dokumenty bez potrzeby instalowania dodatkowego oprogramowania. Książki czytane za pośrednictwem bibliotek cyfrowych cechuje kilka istotnych zalet:

${ }^{6}$ PBI. Wiadomości. [online]. Dostępny w Internecie: http://www.pbi.edu.pl/site. php?p=ZmM1ZjhiNjIwMjY0\&s=YmNmMWFkNGQwNTA2\&a=N2UxNjZmNDIyN DA5 [Data dostępu: 9 maja 2012].

FBC. Łaczna liczba publikacji. [online]. Dostępny w Internecie: http://fbc.pionier.net.pl/owoc/owoc-stats [Data dostępu: 9 maja 2012]. 
- nie trzeba pamiętać o terminie ich zwrotu,

- z jednej pozycji może korzystać wiele osób w tym samym czasie,

- jeżeli ktoś posiada własne łącze internetowe, przeczytanie konkretnej pozycji nie wymaga wychodzenia $\mathrm{z}$ domu, co znacznie oszczędza czas i w wielu przypadkach bywa bardzo pomocne.

Główną wadą bibliotek cyfrowych jest to, że nie znajdziemy w nich nowości wydawniczych, ponieważ są to publikacje, które wciąż chronią prawa autorskie, chyba że autor zezwoli na umieszczenie w nich publikacji. Jeśli jednak nie zaznaczy inaczej, publikację można zdigitalizować i włączyć do biblioteki cyfrowej dopiero 70 lat po śmierci twórcy. Nie dziwi więc niedawny spór sądowy o ustalenie dokładnej daty śmierci zmarłego w 1942 r. Janusza Korczaka ${ }^{8}$, który pozwoli ustalić, czy jego publikacje są jeszcze objęte prawem autorskim majątkowym, czy też nie.

Liczba publikacji udostępnianych w bibliotekach cyfrowych sukcesywnie rośnie ${ }^{9}$, ze zbiorów korzysta coraz więcej użytkowników, można więc przypuszczać, że biblioteki cyfrowe nadal będą się rozwijać i powiększać swe zbiory, także o powieści historyczne.

\section{Bibliografia}

1. Dyczkowski A.: Nowy leksykon PWN. Warszawa: PWN, 1998. ISBN 83-0112490-3

2. Federacja Bibliotek Cyfrowych. Wiadomości. [online]. Dostępny w Internecie: http://fbc.pionier.net.pl/owoc/fbc-news. [Data dostępu: 9.05.2012]

3. Gazda G., Tynecka-Makowska S.: Stownik rodzajów $i$ gatunków literackich. Kraków: „Universitas”, 2006. ISBN 83-242-0474-1

4. Głowiński M.: Stownik terminów literackich. Wrocław: Zakład Narodowy im. Ossolińskich, 1989. ISBN 83-04-01787-3

5. Lublin. Sprawa daty śmierci Janusza Korczaka - w sqdzie. „Gazeta Wyborcza.pl”. [online]. Dostępny w Internecie: http://wyborcza.pl/1,91446, 12375375,Lublin_Sprawa_daty_smierci_Janusza_Korczaka__w_sadzie.html\#ix zz25143NvvQ [Data dostępu: 18.02.2011]

6. PBI. Wiadomości. [online]. Dostępny w Internecie: http://www.pbi.edu.pl/ site.php?p=ZmM1ZjhiNjIwMjY0\&s=YmNmMWFkNGQwNTA2\&a=N2UxNjZ mNDIyNDA5 [data dostępu: 9 maja 2012]

${ }^{8}$ Por. Lublin. Sprawa daty śmierci Janusza Korczaka - w sqdzie. [W:] Gazeta Wyborcza.pl [online]. Dostępny w Internecie: http://wyborcza.pl/1,91446,12375375,Lublin_Sprawa_daty_smierci_Janusza_Korczaka__w_sadzie.html\#ixzz2514 3NvvQ [data dostępu: 30.06.2012].

9 FBC. Łaczna liczba publikacji. [online]. Dostępny w Internecie: http://fbc.pionier.net.pl/owoc/owoc-stats [data dostępu: 9.06.2012]. 
7. Polska Biblioteka Internetowa. [online]. Dostępny w Internecie: http:// www.pbi.edu.pl/ [Data dostępu: 9.05.2012]

8. Stanisławska-Kloc S.: Prawo autorskie a biblioteka cyfrowa - opinia prawna. „Ebib” 2005, nr 9. [online]. Dostępny w Internecie: http://ebib. oss.wroc.pl/2005/70/stanislawska-kloc.php [data dostępu: 18.05.2011] 